УДК: 16.441-002-06:618.29

\section{C.Е. Косілова}

Буковинський державний медичний університет МОЗ України (м. Чернівці, Україна)
ЕУТІРЕОЇДНИЙ ЗОБ, ЯК ФАКТОР РИЗИКУ ПЕРИНАТАЛЬНИХ УСКЛАДНЕНЬ
Ключові слова: вагітність, пологи, новонароджені, щиитоподібна залоза, еутіреоїдний зоб.
Резюме. Розповсюдженість захворювань щчитоподібної залози серед жінок фертильного віку постійно зростає. Частота еутиреоїдного зобу займає одне з перших місиь серед вагітних і складає за даними різних авторів від 30\% до 40\%. Це, у свою чергу, несприятливо впливає на здоров'я майбутньої матері і небезпечне для розвитку плода та новонародженого. Разом з тим, вагітність сама по собі може впливати на розвиток даної патологї щитоподібної залози. Взаємозв'язок ичих проиесів до кіния щзе не вивчено. Проведено клініко-статистичний аналіз перебігу вагітності, пологів і стану новонароджених у 50 жінок $з$ наявністю еутіреоїдного зобу. Отримані результати підтверджують, щзо наявність еутиреоїдного зобу змінила показники материнської гемодинаміки, щзо призводило до порушення матково-плачентарного кровообігу і розвитку плацентарної дисфункиії. Результати досліджень свідчать про ускладнений перебіг вагітності (80\% випадків) та пологів (88\% випадків). За даними обстеження вагітних з'ясовано, щзо чим нижче середній рівень вільного тироксину у матері, тим нижча бальна оцінка стану плода. Аналіз результатів гістологічного дослідження плаценти дозволяє розглядати тиреоїдну патологію як фактор ризику розвитку хронічної плацентарної дисфункиії.

\section{Вступ}

Відповідно до результатів дослідження, у 22 областях України має місце помірний дефіцит йоду $[2,7]$. Нестача йоду призводить до розвитку йододефіцитних станів, які є важливою медико-соціальною проблемою $[1,3,4]$. Розповсюдженість захворювань щитоподібної залози серед жінок фертильного віку постійно зростає. Частота еутіреоїдного зобу займає одне 3 перших місць серед вагітних і складає за даними різних авторів від $30 \%$ до 40\% [3,4]. Це, в свою чергу, несприятливо впливає на здоров'я майбутньої матері та небезпечне для розвитку плода та новонародженого [2,4,6]. Разом 3 тим, вагітність сама по собі може впливати на розвиток даної патології щитоподібної залози. Як відомо, фізіологічна адаптація тіреоїдної системи під час вагітності зумовлена впливом декількох факторів, які підвищують потребу організму в тіреоїдних гормонах і призводять до значної стимуляції щитоподібної залози $[1,4,5,8]$. До таких специфічних факторів відносяться гіперпродукція хоріонічного гонадотропіну, естрогенів і тироксинзв'язуючого глобуліну, підвищення ниркового кліренсу йоду та зміна метаболізму тіреоїдних гормонів матері у зв'язку з активним функціонуванням фетоплацентарного комплексу $[1,2,4,5]$. Взаємозв'язок цих процесів до кінця ще не вивчено. Захворювання щитоподібної залози, як наслідок дефіциту йоду, є найбільш частою ендокринологічною проблемою і викликають особливу зацівленість акушер-гінекологів, так як впливають на перебіг вагітності, пологів і стан новонароджених.

\section{Мета дослідження}

Вивчення особливостей перебігу вагітності та пологів у жінок з еутіреоїдним зобом.

\section{Матеріал та методи дослідження}

Проведено клініко-статистичний аналіз перебігу вагітності, пологів і стану новонароджених у 50 жінок з наявністю еутіреоїдного зобу (основна група). Контрольну групу склали 20 соматично здорових вагітних.

Для визначення стану щитоподібної залози проведено ii ультразвукове дослідження (УЗД) 3 наступною консультацією лікаря-ендокринолога. Радіоімунним методом визначався рівень тіреоїдного гормону (ТТГ) і вільного тіроксіну (Т4) у крові.

3 метою оцінки стану фетоплацентарної системи вивчали показники фетометрії, кількості та якості навколоплідних вод, параметрів матково-плацентарно-плодового кровоплину, оцінювали результати морфологічного дослідження плацент. 
Стан новонароджених оцінювали за шкалою Апгар і по результатам огляду.

Отримані результати опрацьовані методом варіаційного статистичного аналізу з визначенням парного критерію Стьюдента.

\section{Результати дослідження та їх обговорення}

Вік обстежених коливався від 20 до 30 років і в середньому складав $24,51 \pm 2,71$ роки в основній групі і 25,12 $22,21-$ у контрольній ( $>>0,05)$. 3'ясовано, що жінки основної групи мали екстрагенітальну патологію: хронічний пієлонефрит виявлено у 10 (30,3\%) пацієнток, захворювання шлунково-кишкового тракту - у 3 (9,9\%), нейроциркуляторну дистонію - у 17 (15,9\%), захворювання органів дихання - у 3 (9,9\%). При аналізі гінекологічного анамнезу з'ясовано, що порушення менструального циклу мало місце у $10(20 \%)$ пацієнток основної групи і у 1 (5\%) - в контрольній, пізнє менархе - у 5 (10\%) і у 1 (5\%) відповідно, хронічні запальні процеси жіночих статевих органів - у $15(30 \%)$ і у 2 (10\%), відповідно $(\mathrm{p}<0,05)$.

Під час ультразвукового дослідження щитоподібної залози у пацієнток основної групи виявлено збільшення іiї розмірів. Об'єм щитоподібної залози коливався від 19,29 до 38,71 см 3 . У залежності від ступеня збільшення щитоподібної залози був діагностований зоб I ст. у $50 \%$ обстежених, зоб II ст. - у 30\%, третього ступеня - у $20 \%$.

Рівень ТТГ у вагітних із зобом був у межах 0,43-4,0 мМЕ/мл, що відповідає еутіреоїдному стану. Рівень Т4 реєструвався в межах від 6,5 до 18,2 нг/мл у 80\% випадків, що відповідає нормальним показникам. У решти пацієнток (20\%) рівень Т4 вільний був дещо нижчим за норму (від 4,3 до 6,5 нг/мл) при нормальних показниках ТТГ, що свідчить про наявність субклінічного гіпотіреозу.

Аналіз перебігу теперішньої вагітності по-

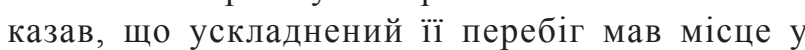
$40(80 \%)$ жінок основної групи і у 5 (25\%) контрольної. Серед ускладнень вагітності частіше всього зустрічались: пієлонефрит - 20\% (10) і 5\% (1), анемія - 52\%(26) і 15\% (3), прееклампсія - 8\% (4) і 5\% (1) в основній і контрольній групах відповідно.

За даними УЗД в основній групі плацента мала нормальну локалізацію у $88 \%$ обстежених, порушення плацентації (крайове, центральне передлежання плаценти) зустрічалось в $12 \%$. Передчасне старіння плаценти, як ознака плацентарної дисфункції, виявлено у 10\% вагітних основної групи. Маловоддя було діагностовано в $22 \%$ випадків, багатоводдя - у 12\%. Порушення параметрів доплерометрії матково- плацентарного кровообігу мало місце у кожної четвертої пацієнтки основної групи і у 5\% (1) в контрольній $(\mathrm{p}<0,05)$. Отримані результати підтверджують, що наявність еутіреоїдного зобу змінила показники материнської гемодинаміки, які приводили до порушення матковоплацентарного кровоплину і розвитку плацентарної дисфункції.

Теперішня вагітність у контрольній групі в $100 \%$ випадків завершилась пологами, а в основній - в 88\% (44). У жінок основної групи самовільне переривання вагітності в ранньому терміні відбулось у 6 (12\%) пацієнток, передчасні пологи - у 4 (8\%). У контрольній групі в 1 (5\%) жінки мав місце передчасний розрив плідних оболонок (ПРПО). У пацієнток основної групи спостерігались наступні ускладнення в пологах: слабкість пологової діяльності - у 4\% (2) випадків, ПРПО - у 2\% (1), кровотеча в пологах - у 4\% (2), важка пре еклампсія - у 2\% (1), дистрес плода - у 4\% (2).

Вивчення серцевої діяльності плода під час кардіотокографії у вагітних із зобом показало, що базальна частота серцевих скорочень серед-

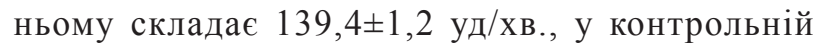

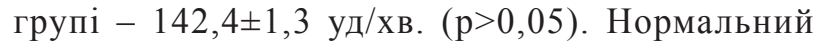
стан новонароджених при народженні (8 балів за шкалою Апгар) було відмічено у 40\% основної групи, зниження адаптації (6-7 балів) - у $56 \%$, асфіксія новонароджених (менше 5 балів) була зареєстрована в 4\% випадків. Середня оцінка новонароджених за шкалою Апгар в основній групі склала 7,1 $\pm 0,1$ бали, що до-

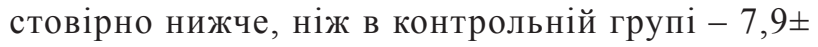
0,1 бали $(\mathrm{p}<0,05)$. При співвставленні функції щитоподібної залози за даними гормональних досліджень і показникам стану плода з'ясовано, що чим нижче середній рівень вільного тіроксину у матері, тим нижча бальна оцінка стану плода $(\mathrm{p}<0,05)$.

3 метою вивчення стану фетоплацентарної системи у жінок із зобом була проведена оцінка результатів гістологічного дослідження плаценти. У 20\% випадків плацента відповідала III триместру вагітності, що розцінювалось як норма, у 80\% обстежених мала місце плацентарна дисфункція, 3 них хронічна плацентарна дисфункція сформувалась у 54\%. Ознаки плацентиту спостерігались в 18 \% випадків. Це дозволяє розглядати тіреоїдну патологію як фактор ризику розвитку хронічної плацентарної дисфункції [2,4].

\section{Висновки}

1. Перебіг вагітності і пологів у жінок з патологією щитоподібної залози ускладнюється достовірно частіше, ніж у здорових жінок.

2. У вагітних з еутіреоїдним зобом часто роз- 
вивається плацентарна дисфункції, що призводить до порушення стану новонароджених.

3. Потрібні подальші дослідження і розробка науково-обгрунтованої тактики ведення вагітності у жінок з еутіреоїдним зобом.

\section{Перспективи подальших досліджень}

Розробка профілактичних заходів при патології щитоподібної залози, що буде сприяти зниженню частоти ускладнень перебігу вагітності та пологів.

\section{Література}

1. Бичевская Р.Г. Особенности течения первого триместра беременности у женщин с невынашиванием на фоне йоддефицита / Р.Г.Бичевская, Н.А.Фирсова // Зб. наук. пр. Асоц. акуш.-гінекол. України. - 2010. - С. 58-61.

2. Бутова Е.А. Йоддефицитные заболевания и беременность / Е.А.Бутова, А.А.Головин, Е.А.Кочергина // Российский вестник акушера-гинеколога. - 2010. - Т.1. - С.12-17.

3. Дедов И.И. Стратегия ликвидации йоддефицитных заболеваний в Российской Федерации / И.И. Дедов, Н.Ю.Свириденко // Проблемы эндокринологии. - 2011. - Т.47, № 6. - С. 1-10.

4. Дёмина Т.Н. Состояние фетоплацентарной системы у беременных с эутиреоидным зобом / Т.Н. Дёмина, Н.В. Асмолова // Зб. наук. пр. Асоц. акуш.-гінекол. України. - 2009. - С. 192-194.

5. Касаткина Э.П. Роль йодного обеспечения в неонатальной адаптации тиреоидной системы / Э.П. Касаткина, Д.Е. Шилин, Л.М. Петрова // Проблемы эндокринологии. - 2010. - Т.47, №3. - С.10-15.

6. Мацынин А.Н. Проблема йоддефицита у беременных промышленной зоны Донбасса / А.Н. Мацынин // 3б. наук. пр. Асоц. акуш.-гінекол. України. - 2009. - С. 440-443.

7. Шідловський В.О. Йодний дефіцит і йододефіцитні захворювання: посіб. для лікаря / В.О. Шідловський, І.М. Дейнеко, О.В. Шідловський. - К., 2004. - 102 с.

8. Moscirka A. The influence of iodine deficiency during pregnancy of fetal and neonatal development / A.Moscirka, J.Gadzinowski // Gynekol. Pol. - 2001. - № 72. - P. 908-916.

\section{ЭУТИРЕОИДНЫЙ ЗОБ, КАК ФАКТОР РИСКА ПЕРИНАТАЛЬНЫХ ОСЛОЖНЕНИЙ}

\section{С.Е. Косилова}

\section{Буковинский государственный медицинский университет МЗ Украины (г. Черновцы, Украина)}

Резюме. Распространенность заболеваний щитовидной железы среди женщин фертильного возраста постоянно растет. Частота эутиреоидного зоба занимает одно из первых мест среди беременных и составляет по данным разных авторов от $30 \%$ до $40 \%$. Это, в свою очередь, неблагоприятно влияет на здоровье будущей матери и опасно для развития плода и новорожденного. Вместе с тем, беременность сама по себе может влиять на развитие данной патологии щитовидной железы. Взаимосвязь этих процессов до конца еще не изучена. Проведен клинико-статистический анализ течения беременности, родов и состояния новорожденных у 50 женщин с наличием эутиреоидного зоба. Полученные результаты подтверждают, что наличие эутиреоидного зоба изменило показатели материнской гемодинамики, что приводило к нарушению маточно-плацентарного кровотока и развития плацентарной дисфункции. Результаты исследований свидетельствуют об осложненном течении беременности ( $80 \%$ случаев) и родов (88\% случаев). По данным обследования беременных выяснено, что чем ниже средний уровень свободного тироксина у матери, тем ниже балльная оценка состояния плода. Анализ результатов гистологического исследования плаценты позволяет рассматривать тиреоидную патологию как фактор риска развития хронической плацентарной дисфункции.

Ключевые слова: беременность, роды, новорожденные, щитовидная железа, эутиреоидный зоб.

\section{EUTHYROID GOITER AS RISK FACTOR OF PERINATAL COMPLICATIONS}

\section{S.Y. Kosilova}

\author{
Bukovinian State Medical University \\ HM of Ukraine \\ (Chernivtsi, Ukraine)
}

Summary. The spread of thyroid diseases among women of fertile age are constantly increasing. The frequency of euthyroid goiter occupies one of the first places among the pregnant and constitutes from $30 \%$ to $40 \%$ according to the data of various authors. At the same time, it has an unfavorable influence on the health of a future mother and it is dangerous for the development of the fetus and newborn. In addition, pregnancy itself can affect the development of the given pathology. Interrelation of these processes is not completely studied. Clinical-statistical analysis of the course of pregnancy, labor and newborn state among 50 women with euthyroid goiter has been conducted. The obtained results confirm that euthyroid goiter changed the indices of maternal hemodynamic leading to disorders of the uterine-placental blood circulation and development of placental dysfunction. The results of investigation testify about complicated flow of pregnancy $(80 \%$ of cases) and labor (88\% cases). The examination found that the lower level of free thyroxin of mother correlated with the lower scale evaluation of the fetus. Results of histological examinations of placentas interpret thyroid pathology as the risk factor promoting the development of chronic placental dysfunction.

Keywords: pregnancy, labor, newborns, thyroid gland, euthyroid goiter 